The University of Maine

\title{
DigitalCommons@UMaine
}

English Faculty Scholarship

English

1983

\section{Willy Loman and the "Soul of a New Machine": Technology and the Common Man}

Richard T. Brucher

University of Maine - Main, richard.brucher@umit.maine.edu

Follow this and additional works at: https://digitalcommons.library.umaine.edu/eng_facpub

Part of the English Language and Literature Commons

\section{Repository Citation}

Brucher, Richard T., "Willy Loman and the "Soul of a New Machine": Technology and the Common Man" (1983). English Faculty Scholarship. 7.

https://digitalcommons.library.umaine.edu/eng_facpub/7 


\title{
Willy Loman and The Soul of a New Machine: Technology and the Common Man
}

\author{
RICHARD T. BRUCHER
}

As Death of a Salesman opens, Willy Loman returns home "tired to the death" (p. 1 3 ). ${ }^{1}$ Lost in reveries about the beautiful countryside and the past, he's been driving off the road; and now he wants a cheese sandwich. But Linda's suggestion that he try a new American-type cheese - "It's whipped" (p. 16) - irritates Willy: "Why do you get American when I like Swiss?" (p. 17). His anger at being contradicted unleashes an indictment of modern industrialized America :

The street is lined with cars. There's not a breath of fresh air in the neighborhood. The grass don't grow any more, you can't raise a carrot in the back yard. (p. 17).

In the old days, "This time of year it was lilac and wisteria." Now : "Smell the stink from that apartment house! And another one on the other side..." (pp. I 7-I 8). But just as Willy defines the conflict between nature and industry, he pauses and simply wonders: "How can they whip cheese?" (p. I 8).

The clash between the old agrarian ideal and capitalistic enterprise is well documented in the literature on Death of a Salesman, as is the spiritual shift from Thomas Jefferson to Andrew Carnegie to Dale Carnegie that the play reflects. ${ }^{2}$ The son of a pioneer inventor and the slave to broken Richard T. Brucher is Associate Professor of English at the University of Maine, Orono, Maine 04469 .

1 Arthur Miller's Death of a Salesman (1949) is quoted from the Viking Critical Edition, ed. Gerald Weales (New York: Viking Press, 1967).

2 See Barclay W. Bates, "The Lost Past in Death of a Salesman," Modern Drama, II (1968), 164-72; Chester E. Eisinger, "Focus on Arthur Miller's Death of a Salesman: The Wrong Dreams," in American Dreams, American Nightmares, ed. David Madden (Carbondale: Southern Illinois Univ. Press, 1970), pp. 165-74; Barry Edward Gross, "Peddler and Pioneer in Death of a Salesman," Modern Drama, 7 (1969), 405-10; and Gerald Weales, “Arthur Miller: Man and His Image," in Arthur Miller, Death of a Salesman, ed. Gerald Weales, pp. 350-66.

Journal of American Studies, 17 (1983), 3, 325-336 Printed in Great Britain 
machines, Willy Loman seems to epitomize the victim of modern technology. But his unexpected, marvelingly innocent question about whipping cheese reveals an ambivalence toward technology livelier and more interesting (and perhaps truer to the American character) than a simple dichotomy between farm and factory, past and present. Death of a Salseman engages an audience's conflicting attitudes toward technology: fear of the new and unfamiliar; marvel at progress; and the need, finally, to accommodate technology to cultural mythologies by subordinating it to personality. Willy's contradictions clearly indicate his alienation, but they recall Walt Whitman, too (that other restless Brooklynite who could sing enthusiastically of leaves of grass, lilacs, and locomotives in winter). "Do I contradict myself?" Whitman asks near the end of Song of Myself; "Very well then I contradict myself, I (I am large, I contain multitudes.)" (p. 76$).^{3}$

In "Passage to India," Whitman says that after the engineers, inventors, and scientists have accomplished their work,

Finally shall come the poet worthy of that name,

The true son of God shall come singing his songs. (p. 342)

I do not claim the status of Whitman's divine poet for either Arthur Miller or Tracy Kidder, the author of The Soul of a New Machine. But both are fine connectors who invoke the spirit of Whitman, Thoreau, and Emerson as they help us integrate technology with cultural mythologies and thus triumph over it in the popular imagination. Indeed, the great American writers of the nineteenth century define, in part, the tradition into which some contemporary writers try to fit modern technological enterprise.

Miller endows Willy Loman with a Whitmanesque urge to appropriate technology to his personal vision, not just consume it. This quality complicates Willy's relationship with technology, and thus the whole notion of his pathetic victimization. Willy's Whitmanesque impulses help define the need to appropriate technology to American cultural values, and to allay the fear, voiced by Norman Mailer in Of a Fire on the Moon, that "The art of communication has become the mechanical function, and the machine... the work of art" (p. 55). ${ }^{4}$ By defining the problem and impulse, Death of a Salesman creates a context for interpreting Kidder's attempt, in The Soul of a New Machine, to bring computer technology into the American popular culture and literary tradition.

3 Whitman is quoted from Leaves of Grass and Selected Prose, ed. Sculley Bradley (San Francisco: Rinehart Press, Rinehart Editions, 1955).

4 Norman Mailer, Of a Fire on the Moon (1970; paper rpt. New York: New American Library, 1971), p. 55 . 
The Soul of a New Machine does not answer the question of how they whip cheese, but it explains how some people build computers: with intelligence, imagination, enthusiasm, and sheer hard work. Kidder casts his "new journalism" report of how the Data General Corporation developed "Eagle," a 32-bit minicomputer, as a high-tech frontier tale. Tom West, the computer engineer-manager and folksinger who leads the Data General team, the Eclipse Group, seems to be the new American Adam, an aggressive business manager and dropout at the same time. As a success story, a story of men and women who refuse to be defeated by machines, The Soul of a New Machine seems to refute the failure dramatized in Death of a Salesman. Except that as Eagle goes out the door - renamed by marketing men the "Eclipse MV/8000" - a few of its builders go with it. The verge toward Salesman is an irony I'll return to later. Rather than show easy resolutions to the conflicts between individualism, technology, and corporate impersonality, Kidder recasts some of the fundamental questions.

Death of a Salesman and The Soul of a New Macbine impose arbitrary limits on a huge topic. As Leo Marx argues in The Machine in the Garden, the goal of establishing an American "society of the middle landscape, a rural nation exhibiting a happy balance of art [including science] and nature," goes back at least to the eighteenth century. "But no one, not even Jefferson, had been able to identify the point of arrest, the critical moment when the tilt might be expected and progress cease to be progress." 5 We all set personal, arbitrary limits on acceptable technology. Wilbur Moore, an old black mechanic, once told me that western civilization fell into decline when Chevrolet went from six- to eight-cylinder engines. Tom West, the Data General engineer, draws the line at digital wristwatches:

Anyone who dared to consult such a chronometer and in [West's] hearing say, "the exact time is...," could expect to receive the full force of his scorn, for being such a fool as to think that a watch was accurate just because it had no hands. (p. 180$)^{6}$

One winter night, while stirring logs in his fireplace, West mutters, "Computers are irrelevant" (p. I 80).

As the limits of technology shift, so do our means of coping with it and incorporating it into the popular culture. Steve Goodman's song, "The City of New Orleans," wistfully ritualizes the end of a passenger

5 Leo Marx, The Machine in the Garden: Technology and the Pastoral Ideal in America (1964; paper rpt. New York: Oxford Univ. Press, 1973), p. 226.

${ }_{6}$ Tracy Kidder, The Soul of a New Macbine (Boston: Little, Brown, 1981). All quotations are from this edition. 
train, while the homes, farms, and fields the train passes on its last run endure. The conflict between technology and nature has been nicely revalued. Corvette Summer, an otherwise unremarkable movie, concludes with an interesting variation of the obligatory car chase. The bad guy runs his car off the end of the pavement on a highway construction site. The car, as I recall, careers down an embankment, rolls over, and comes to rest, demolished, on another pavement. As the driver staggers from the wreck, the car's horn blares mournfully. The driver shoots the car dead with one well-placed bullet. If you can kill a machine, with remorse as a cowboy does his crippled horse, you have managed a marvelous control over it; and you have brought it into the typology of the American West. Walt Whitman, who according to Leo Marx "comes [the] closest [of our nineteenth-century writers] to transmuting the rhetoric of the technological sublime into poetry" (p. 222), can turn a locomotive into a sexual object: "Thee in thy panoply, thy measur'd dual throbbing and thy beat convulsive..." (p. 386). If you can sodomize a machine, if only in the imagination, you have asserted a peculiar but persuasive control over it.

Whitman haunts Death of a Salesman, especially in the scene in boss Howard's office, in which Willy is fired. This is a critical moment in Willy's life, as he goes in to plead for a New York job after spending thirty-four years on the road. It is the play's most blatantly anti-business scene: "it's a business, kid," young Howard explains to old Willy just before he sacks him, "and everybody's gotta pull his own weight" (p. 80). On the surface, it is also the play's most obviously anti-technology scene, for throughout most of it Howard is preoccupied with his new toy, a wire recorder. It "records things," Howard explains enthusiastically:

I tell you, Willy, I'm gonna take my camera, and my bandsaw, and all my hobbies, and out they go. This is the most fascinating relaxation I ever found. (pp. 76 , 78)

As Willy's life falls apart, the voice of Howard's five-year-old son, recorded on the wire, intones the capitals of the states: "The capital of Alabama is Montgomery; the capital of Arizona is Phoenix; the capital of Arkansas is Little Rock..." (p. 77). The episode is a savagely comic, yet pathetic, mockery of Whitman's America, evoked through its place names, and his celebration of common people.

But in the middle of this scene Willy celebrates Dave Singleman, the old drummer who at the age of eighty-four could still make his living with pride and dignity by going up to his hotel room, putting on his green velvet slippers, and calling the buyers on the phone. Singleman is a troublesome 
figure; he works and lives alone, and we do not know how much Willy has exaggerated his success over the years. But Willy links Singleman with his own father (also a loner) and commerce with the American frontier:

Oh, yeah, my father lived many years in Alaska. He was an adventurous man. We've got quite a little streak of self-reliance in our family. I thought I'd go out with my older brother and try to locate him, and maybe settle in the North with the old man. And I almost decided to go, when I met a salesman in the Parker House. His name was Dave Singleman. (p. 8I)

Most persuasively, Willy apotheosizes Singleman in an unexpectedly eloquent, genuinely Whitmanesque passage that includes an image of technology, the train:

Do you know? when he died - and by the way he died the death of a salesman, in his green velvet slippers in the smoker of the New York, New Haven and Hartford, going into Boston - when he died, hundreds of salesmen and buyers were at his funeral... In those days there was personality in it, Howard. There was respect, and comradeship, and gratitude in it. (p. $8 \mathrm{I}$ )

The reference to "personality" does not sway Howard because he is not listening. But we are listening as the speech - Willy's longest in the play - swells out of the painful conflicts between boss and employee, parents and children, men and machines. Speaking with the eloquent desperation of a person clinging to his job and vision - his very identity Willy captures Whitman's sweep and rhythm, his balance of particular and generalization, place and motion. Purpose, movement, and activity infuse Willy's naming of places, as the names define both the cities and the railroad that serves them. He invokes Emerson's spirit of self-reliance, the wilderness, and the newer frontier of American commerce that he must endow with epic qualities. The speech conveys the "enterprise and bravery" of commerce that even Thoreau admires (with some irony) as the Fitchburg train breaks the peace at Walden Pond.

It may be that Willy never recognizes "that there is more than one way to kill a salesman" (Weales, p. 356). But it is apparent, too, that there is more to "personality" than is dreamt of in the philosophy that Dale Carnegie propounds in How to Win Friends and Influence People. Willy puts

7 See Walden (1 854 ), especially Chapter 4, "Sounds": "What recommends commerce to me is its enterprise and bravery...I see these men every day go about their business with more or less courage and content, doing more even than they suspect, and perchance better employed than they could have consciously devised." Quoted from the Signet edition of Walden, ed. Perry Miller (New York: New American Library, 1960), p. 84 . 
us back in touch with that idealized New England cult of personality called transcendentalism. Willy, the apparent victim of technology - he will kill himself in a car wreck - shows us how we can, and perhaps must, integrate technology and personality with a rich cultural past. This is one reason why, as Linda insists, "attention must be finally paid to such a person" (p. 56): Willy's metaphoric quest distinguishes him from the rest of the characters in the play and many in the audience. Howard, by contrast, is a forties' version of the unthinking consumer of fashionable technology, the first in line at Sears to buy "Pac Man."

But video games should not be singled out for derision. They are, after all, offshoots of pinball games; and pinball has a long tradition in popular culture as a point at which people and machines connect. ${ }^{8}$ There is, for example, a wonderful moment in William Saroyan's The Time of Your Life when Willie, the marble-ball maniac, beats the machine in Nick's Pacific Street Saloon, Restaurant, and Entertainment Palace. It only takes Willie six nickels (though most of the day) to triumph, and the results are spectacular. The machine's lights flash, some red, some green, and an American flag jumps up. "Oh, boy, what a beautiful country," Willie says as the machine plays " $A$ loud music-box version of the song "America", (p. 463). ${ }^{9}$ Several characters stand up and sing along with the machine. "Everybody," the stage directions tell us, "bas watched the performance of the defeated machine from wherever he bappened to be when the performance began." Willie is "thrilled, amazed, delighted":

Took me a little while, but I finally did it. It's scientific, really. With a little skill a man can make a modest living beating the marble games. Not that that's what I want to do. I just don't like the idea of anything getting the best of me. A machine or anything else. (p. 463)

The Time of Your Life is a beatific, wish-fulfilling fantasy. Even Murphy, a.k.a. Kit Carson, the teller of tall tales, lives out his fantasies about the

8 But see Frank Deford, “Are Electronic Video Games Bad for Kids? Well, Really and Not Really," Sports Illustrated, 57: 16 (i I Oct. 1982), 6-7, 10: "Video games are not sophisticated pinball machines... The quiddity of video games is that they are patterned... They can't tilt! It's all rote" (p. 10). Pinball games, on the other hand, " require a certain imaginative dexterity. They may even be a metaphor for life . . because the trick with pinball games is to know how to stretch, even to sorta kinda exceed the limits... but ever so gingerly - to caress some extra points out of the machine without ever quite tilting the whole shebang. Pinball teaches you to skirt, to fudge, to finagle, to take sensible risks" (p. 7).

9 The Time of Your Life (1939) is quoted from Famous American Plays of the 1930's, ed. Harold Clurman (New York: Dell, Laurel Drama Series, 1959). 
Old West when, at the end, he shoots Blick, vice squad captain and the only vicious character in the play:

I shot a man once. In San Francisco. Shot him two times. In 1939, I think it was. In October. Fellow named Blick or Glick or something like that. Couldn't stand the way he talked to ladies. (p. 480)

Saroyan's play did not test American ideas and assumptions the way Death of a Salesman was to do ten years later; Saroyan plays on nostalgia, whereas Miller tests the assumptions on which the nostalgia is based. But the marble game and the echo of the Old West are good examples of the kind of mythic appropriation I have been describing. They depend heavily on familiar cultural idioms and rhythms, revived in twentieth-century circumstances, for achieving comic release and audience awareness. They contribute some ambivalence, too: has the machine really been defeated? Or has it been released to display a hidden array of electronic/mechanical wizardry that delights an audience once it has fulfilled its purpose of challenging the operator?

A colleague told me the story of some enterprising student engineers at Stanford in the early I 970 . For senior projects they had to build devices that could, under their own power, climb a flight of stairs. The winners, this one year, built a robot that climbed the stairs, shot up an American flag, played the "Star Spangled Banner," and then blew itself up. That is a triumph over technology that even Willie, the marble-game maniac, might envy. The students first had to design and build the machine, programming it to destroy itself as a demonstration of their domination over it (and as a comment, perhaps, on America's technological prowess). I offer this anecdote not as an example of programmed obsolescence, but as a literal demonstration of what Tom West says is the compulsive need never to look back: “'The old things [i.e., last year's computers], I can't bear to look at them. They're clumsy. I can't believe we were that dumb" (p. I 80). This need to dominate the machine characterizes the engineers depicted in Kidder's The Soul of a New Machine, and it links them, within modest limits, to the fighter pilots turned astronauts celebrated hyperbolically in Tom Wolfe's The Right Stuff.

Style and self dramatization declare the nature and significance of the human domination of technology. Saroyan's Willie needs to beat the machine to be able to reassert the American myth of individualism and multiplicity (here, ethnic multiplicity):

(Indicating the letter " $F$ " on his sweater) See that letter? That don't stand for some little-bitty high school somewhere. That stands for me. Faroughli. Willie Faroughli. I'm an Assyrian. (p. 463) 
Miller's Willy must also assert his identity when charged by his son to know himself better: "I am not a dime a dozen! I am Willy Loman, and you are Biff Loman!” (p. I 32). Here Willy Loman does more than embrace "the American myth, born of the advertisers," that confuses "labels with reality" (Weales, p. 356). The myth is deeper than that, for here Willy echoes, like Saroyan's Willie before him, Walt Whitman's bold declaration of self in Song of Myself:

Walt Whitman, a kosmos, of Manhattan the son,

Turbulent, fleshy, sensual, eating, drinking and breeding,

No sentimentalist, no stander above men and women or apart from them,

No more modest than immodest. (p. 44)

Willy Loman, even as he collapses under the weight of his own cultural baggage, feels compelled to fit technology into his inherited vision of American enterprise, to bring it under the control of language inspired by Whitman. Reshaping the technological environment with a vision born of language, making it conform to the culture created and articulated by its people, may finally be the most significant triumph over the machine.

This second feat - appropriating the technology into the myth, not just mastering or applying it - makes Kidder's book persuasive and helps overcome our suspicions about the dehumanizing power of computers. Rather than computer technology, The Soul of a New Machine celebrates a few of the people who build computers. To make the technology and the drama accessible, Kidder invokes the kinds of tropes and expressions that I've been describing. Carl Alsing, the leader of the "Microkids" and, at 35 , one of West's trusted old men (as well as his observer, his Boswell), describes a "war" between Data General's Massachusetts and North Carolina research teams as "the big shoot-out at HoJo's." He imagines it as "a pen-and-ink drawing [in which] snarling engineers are shown hurling complexities at each other" (p. 38 ). The enigmatic Tom West, who rarely talks to his recruits the whole time they are building Eagle, is finally described by a team member as a hired gunslinger - a kind of corporate Johnny Ringo - who cleans up the town but then is run out by the respectable people. "That's a classic American story," remarks Alsing (p. 280), warming at once to the appropriateness of the analogy.

Such analogies help the engineers order their own experience and give it meaning, and they define, in an important way, Kidder's methods of taking us into the high-tech wilderness of computer engineering. Alsing uses the computer game "Adventure" to break in his new recruits on their Data General machine and to introduce Kidder to the engineers' mystical experience of midnight programming. Playing Adventure, "you travel by 
computer into an underground world, wandering through strange, awful labyrinths, searching for treasure that's guarded and sometimes snatched away by dragons, dwarfs, trolls, and a rapacious pirate who mutters: 'Har. Har"" (p. 40). A metaphor for the underground world of computer research and development, "The game is a harrowing of hell," because you get lost in a series of mazes that test your very sanity:

I had the feeling I was lost in a forest, and I acted as no smart woodsman would, heading off in this direction, then heading off in that, getting nowhere.

Then I heard Alsing chuckle. "Ahhh, I love it... What do you do when you get lost?"

"You make maps, of course."

Alsing sat back and nodded, smiling...(p. 88)

Thus Leatherstocking teases and leads the neophyte into the wilderness. The neophyte's experience becomes the bridge between two cultures, as Kidder leads the rest of us into the wilderness, civilizing it and toughening us as he goes.

But even Alsing as Leatherstocking is only one sign on Kidder's map into the deep woods. Rather than just make the unfamiliar familiar, the frontier metaphors gradually reveal that technology is a worthy adversary for adventurous spirits. Instead of wolves, hostile Indians, and broken wagon wheels, the new wilderness consists of missing NAND gates, the indecisiveness of logic designers, and the like (p. I48). Such travails define the new wilderness that must be charted. Indeed, Kidder tells us, "A computer's boards seem to show order triumphing over complexity" (p. 31). That notion seems to be the metaphysical point of computer technology for the Data General engineers, and especially for Tom West.

Branded an under-achiever at Amherst College, West dropped out for a year and sang folksongs in Cambridge, Massachusetts. He knew the chaos of the early i $960 s$, and he sought out meaning and order. Instead of retiring to Walden Pond or the Maine Woods, West dropped into engineering.

I think I wanted to see how complicated things happen. There's some notion of control, it seems to me, that you can derive in a world full of confusion if you at least understand how things get put together. Even if you can't understand every little part, how infernal machines get put together. (pp. 175-76)

West insists on living a double life as high-powered manager and dropout, sometimes driving directly to work, ready to play the tough manager, after playing his guitar all night. The 32-bit Eagle would process information more quickly and efficiently than its competitors, and it would stretch the capabilities of its young inventors in ways they had never been stretched before. Building the superminicomputer, then, gives West the opportunity 
to reconcile two opposite ambitions: "He was back in Cambridge, as it were, singing folk songs, while at the same time putting money on Data General's bottom line. He could be, for a while, a balladeer of computers" (pp. 275-76).

"Balladeer of Computers" is something of a misnomer. West is a namer, a coiner of phrases, as well as an amateur folksinger. But he does not sing of computers; he sings of people and their work. His figurative language having "shootouts," "beating up" people, persuading them to "sign up" behind his group's project, "playing pinball" (that is, getting a machine out the door with your name on it so that you win another, more inspiring project to develop), creates a rough-and-tumble world that comes to define the Eclipse Group's workplace and the team members' intensity. West's words, at least to Alsing, have a transforming power. After the Eclipse Group loses its bid to build EGO, its first challenge to the North Carolina team's project, West brings his team out of its depression "into the honesty of pure work" (p. 45), achieving a persuasively New England salvation. Because West finds romance and excitement in the ordinary - a sudden weather change at sea or the challenge of reducing the number of circuit boards in a computer - he manages to turn the Eagle project, a relatively uninteresting computer as far as "sexy" machines go, into an extraordinary event. According to Alsing, "West... took a bag on the side of the Eclipse and made it the most exciting thing in our lives for a year and a half" (p. 275).

That describes a kind of effective management that might appeal to Whitman or Thoreau, even Willy Loman, but not to Willy's boss, Howard. The dogged quest for a missing NAND gate, a little circuit that gives a "not yet" signal to an electrical charge, lends almost epic qualities to the builders' debugging efforts. But the' successful search ends simply, and in the best folk tradition the engineers underplay their achievement. Rather than give the NAND gate a formal, technical name, as is usually done in formal, bureaucratic organizations, the Eclipse engineers use the vernacular "NOT YET" because that describes exactly what the NAND gate's signal says. The effort to "simplify" reflects West's general approach to technological matters: "No muss, no fuss" (p. 209).

The quest to reduce complexity while creating a commercially successful product makes the building of Eagle a kind of high-tech metaphor for Thoreau's experience at Walden. The analogy may be whimsical (Kidder does not go so far as to make it explicit); certainly it is ironic. Tom West retreats each night to his old New England farmhouse, leaving Data General at a distance that cannot be measured in miles or minutes. 
Nevertheless, it is on the job, or at home when thoughts of work intrude, that solving the practical problems of computer engineering becomes the effective equivalent of attempting to live simply, in tune with nature and oneself .

"Pinball" is the key concept, now in an elaborate, "real world" extension of the inspiration that Willie the marble-ball maniac enjoys. Signing up to work long hours, with no pay for overtime and few company resources, to get a machine out the door with your name on it, is exhausting and frustrating. The stakes are high, however. In playing pinball, the computer designer is playing, finally, for "substantial freedom ": freedom to work on the projects he wants, the way he wants, and to put his name on his work (p. 282). The game is compelling for those who chucked the established ways, as West puts it, because it offers "Some notion of insecurity and challenge, of where the edges are, of finding out what you can't do, all within a perfectly justifiable scenario" (p. I8 I). Pinball benefits the company materially, but it seems to benefit the individual workers spiritually even more. That is its subversive appeal.

The success of the Eagle project seems to rebut the failure and alienation Miller dramatizes in Death of a Salesman, except that the project does not end the way West thought it would. West leaves the Eclipse Group to take another job in the company, a job that would take him often, appropriately, to the Far East. Most of the young engineers get to play pinball, but most of the older ones-West's lieutenants - leave the company. Stripped of most of his managerial responsibilities at Data General, Carl Alsing, for example, takes a job in California. Echoing Willy Loman, Alsing explains that he felt unappreciated by the company. The verge toward Salesman reminds us that the problem is not with technology per se; rather, it is with organizations that mimic the impersonal responses of machines. Society is still a "joint-stock company" that "loves not realities and creators, but names and customs," as Emerson says. ${ }^{10}$

But the human failure of corporations is not the most important link between Salesman and Soul. The more important connection is the assertion of personal identity within the environment of business and technology. Aside from the insistence on tragedy, what Arthur Miller says in "Tragedy and the Common Man" about the modern hero applies to a person like Tom West as well as to characters like Willy Loman and Willie the marble-ball maniac (a delightfully comic figure): the individual's struggle

10 See Emerson's “Self-Reliance," in Selected Writings of Ralph Waldo Emerson, ed. Brooks Atkinson (New York: The Modern Library, Modern Library College Editions, 1950), p. 148 . 


\section{Richard T. Brucher}

to claim his whole due as a personality demonstrates the indestructible will of man to achieve his humanity. ${ }^{11}$ Robert Pirsig, in Zen and the Art of Motorcycle Maintenance, calls for a reassertion of thought and personality in technological matters, as does Mailer, in another, more flamboyant, vein in Of a Fire on the Moon. Even more flamboyantly, indomitable personality characterizes Tom Wolfe's brethren of "the right stuff," the test pilots who keep alive in the sky the raucous qualities of legendary backwoodsmen.

What is finally compelling about Willy Loman and Tom West is their compulsive need to dramatize their work, to redefine it with words that evoke the American past and its values of personality and individualism, and then through their work seek substantial freedom. Miller and Kidder invoke the spirit of Whitman, Thoreau, and Emerson, who before them sought peace with technology while defining a new individualism and freedom. The language of Salesman and Soul connects the individual with a large, often richly contradictory tradition of popular American myth. At least one important form of accommodation of the human to the technological is achieved through this kind of mythmaking. It may be, of course, that computer technology is yet another "improved means to an unimproved end," as Thoreau puts it (Walden, p. 40). But in terms of the writers' abilities to appropriate technology to the popular culture, and to reassert the individual's imaginative control over the machine, the "tilt," the moment when progress ceases to be progress and the system crashes, seems not yet to have occurred.

11 See "Tragedy and the Common Man" (1949), reprinted in the Viking Critical Edition of Death of a Salesman, ed. Weales, pp. 146-47. 